UDK 392:291.33(497.5 Istra)"18"(093)

929 Žiža, Stjepan

929 Plaštinski, Josip

Primljeno: 3. 4. 2017.

Prihvaćeno: 1. 6. 2017.

Izvorni znanstveni rad

DOI: $10.22586 /$ pp.v52i0.7

\title{
Za osvetu, požudu i krađu. Magijske radnje stanovnika Istre 19. stoljeća kao odraz nepovoljnoga socioekonomskog stanja ${ }^{1}$
}

\author{
Luka Šešo \\ Hrvatsko katoličko sveučilište \\ Ilica 242 \\ 10000 Zagreb \\ Republika Hrvatska \\ E-adresa: luka.seso@unicath.hr
}

U radu se analizira rukopis Stjepana Žiže Običaji hrvatskog naroda Istre te rukopis Narodni život Hrvata $i$ Slovenaca u Istri Josipa Ptašinskoga. Oba rukopisa nastala su koncem 19. stoljeća te opisuju magijske radnje istarskih stanovnika s početka stoljeća. Opisane magijske radnje mogu se grupirati na one kojima se ljudi osvećuju, kojima zadovoljavaju požudu, olakšavaju krađu te osiguravaju zdravlje i neranjivost. Sve analizirane magijske radnje podrazumijevale su svetogrđe, brutalnost i suradnju s vragom. Krećući od komentara samih autora rukopisa, koji ističu svoju zabrinutost nad bezbožnim postupcima vršitelja magijskih radnji, u radu se analizira period u kojemu su te radnje prakticirane. Ukazuje se na dramatično socioekonomsko stanje u Istri u prvim desetljećima 19. stoljeća te se raspravlja o magijskim radnjama kao mogućim postupcima pomoću kojih su pojedinci pokušavali premostiti svakodnevne nedaće.

Ključne riječi: magijske radnje, Istra, devetnaesto stoljeće, rukopisi, Stjepan Žiža, Josip Ptašinski, epidemija, glad, seljačko društvo.

\section{Uvod}

"Govore da se more začarati da sama djevojka idje za mladićem. I ovu stvar da se postigne s mrtvačkima kosti, koje se uzmu u groblju reć bi upravo u 12 ili pol

\footnotetext{
1 Ovaj je rad sufinancirala Hrvatska zaklada za znanost projektom "Naracije straha: od starih zapisa do nove usmenosti", broj IP-2016-06-2463.
} 
noći nekoje posebne dane, takovu neku kost se stavi pod platno na oltar dokle svećenik misi, pa se još nešto tada govori, najprije da on laže kada misi. S onom kostju se mora taknuti djevojku, koju se hoće imati, onda ona sama da ide s njim, i da ga nepusti dokle je živ. Ako ju takne s onom koštjom na golo, ona dodje za njim gola." ${ }^{2}$

Prije nego se detaljnije posvetimo navedenome opisu jedne od brojnih magijskih radnji, koju je u svojemu rukopisu zapisao devetnaestostoljetni sakupljač tradicijskih običaja Stjepan Žiža, potrebno je nešto više reći o kakvome je rukopisu riječ (kao i rukopisima s istarskim gradivom). Stoga valja započeti s Odborom za narodni život i običaje (dalje Odbor), koji je 1888. osnovan pod okriljem Jugoslavenske akademije znanosti i umjetnosti u Zagrebu (danas Hrvatska akademija znanosti i umjetnosti). Odmah pri osnutku Odbor je pokrenuo projekt sustavnoga prikupljanja gradiva o narodnome životu i običajima čije je istraživanje trebalo pripomoći izgradnji nacionalnoga identiteta hrvatskoga (i drugih južnoslavenskih) naroda. ${ }^{3}$ Iako će prvi rukopisi s gradivom početi pristizati u Odbor nedugo nakon njegova osnutka, važniji prinosi svoje će mjesto na arhivskim policama pronaći tek nakon što je Antun Radić godine 1897. imenovan glavnim urednikom novoosnovanoga Zbornika za narodni život i običaje Južnih Slavena (dalje Zbornik), koji je Odbor počeo izdavati godinu dana ranije. Zamisao vodstva Odbora $^{4}$ i Antuna Radića bila je da se u Zborniku objavljuju dijelovi rukopisnoga gradiva koje će na terenu sakupljati "seoska inteligencija" po detaljno izrađenim naputcima samoga Radića. Naputke za prikupljanje gradiva Radić će objaviti već 1897. godine u drugome broju Zbornika pod nazivom Osnova za sabiranje i proučavanje građe o narodnom životu (dalje Osnova) te će tim činom započeti plodna Radićeva suradnja s brojnim suradnicima na terenu koji će u Odbor slati prikupljeno gradivo. ${ }^{6}$

\footnotetext{
2 Stjepan Žiža, Običaji hrvatskog naroda Istre. 1895. Hrvatska - Odsjek za etnologiju Hrvatske akademije znanosti i umjetnosti (dalje: ETNOHAZU) - fond Stara zbirka (dalje: SZ), kut. 72, fasc. bII, 11.

U radu će se magijske radnje i drugi dijelovi rukopisa prenositi onako kako su ih zapisali njihovi autori, to jest na vernakularnome jeziku. Tijekom transkribiranja nisu poduzimane nikakve stilske, gramatičke i pravopisne preinake. Treba spomenuti da je jedan manji dio magijskih radnji, koje u svojemu rukopisu opisuje Stjepan Žiža, objavljen 1919. godine u Zborniku za narodni život i običaje. Međutim, u objavljenome tekstu unesene su mnoge stilske i pravopisne preinake, stoga i taj dio magijskih radnji u radu obrađujem na temelju izvornika. Vidi: Stjepan Žiža, "Čarolije. (Iz Istre)", Zbornik za narodni život i običaje 19 (1914), br. 1: 190-191.

3 Jakša Primorac, "Arhivska građa Odsjeka za etnologiju HAZU”, Zbornik za narodni život i običaje 55 (2010): 9-11; Mirko Marković, "Osvrt na stogodišnjici rad Odbora za narodni život i običaje", u: Spomen-spis povodom obilježavanja stogodišnjice postojanja i rada Odbora za narodni život i običaje Južnih Slavena u sastavu Jugoslavenske akademije 1888-1988., ur. Andre Mohorovičić (Zagreb: Jugoslavenska akademija znanosti i umjetnosti, Odbor za narodni život i običaje, 1988), 13-17.

4 Primorac, "Arhivska građa", 19-22; Marković, "Osvrt", 17-24.

5 Pod terminom "seoska inteligencija” Antun Radić podrazumijevao je pismene seljake, seoske učitelje, svećenike i trgovce, to jest pismene i obrazovane pojedince koji žive na selu i poznaju ljude i njihove običaje. Antun Radić, "Osnova za sabiranje i proučavanje građe o narodnom životu", Zbornik za narodni život i običaje Južnih Slavena 2 (1897): 72-73.
}

6 Primorac, "Arhivska građa", 19 
Među brojnim rukopisima u Odbor će pristići i dva rukopisa posebno zanimljiva za ovaj rad. Riječ je o rukopisu već spomenutoga učitelja Stjepana Žiže naslovljenome Običaji hrvatskog naroda Istre te rukopisu Narodni život Hrvata i Slovenaca u Istri Josipa Ptašinskoga. ${ }^{7}$ Gradivo, objedinjeno u dvanaest bilježnica, Žiža je prikupljao u periodu od 1895. do 1899. godine za vrijeme svojega službovanja u jednorazrednoj pučkoj školi u Rovinjskome Selu. U prilog tome da je riječ o vrijednome doprinosu pripadnika seoske inteligencije, kako je zamišljao Radić, ide i činjenica da je Žiža rođen 1851. godine u Kosinožićima kraj Poreča. Završio je četverogodišnju učiteljsku školu u Trstu, uveo je nastavu na hrvatskome jeziku $\mathrm{u}$ školi u Rovinjskome Selu te je u istome mjestu osnovao Narodnu čitaonicu 1898. godine. ${ }^{8}$ Josip Ptašinski, rodom iz Krasnoga u Češkoj, postao je 1892. godine župnikom u istarskome mjestu Sveti Ivan od Šterne te se istaknuo kao narodni preporoditelj potičući čuvanje slavenskih tradicijskih vrijednosti pred prodorom modernizacije. ${ }^{9}$ Svoj rukopis od devet dijelova kompletirao je 1899. godine.

Oba rukopisa predstavljaju svojevrstan pregled tradicijskoga života i običaja $\mathrm{Hr}$ vata (mnogo manje Slovenaca) u Istri. Međutim, unutar brojnih podataka i opisa života istarskih Hrvata, pozornost nam privlače opisi i komentari magijskih radnji koje oba autora nazivaju "čarovijama." Žiža ih obrađuje u dijelovima triju bilježnica, u kojima zapisuje tradicijska vjerovanja, dok ih Ptašinski smješta u osmu bilježnicu rukopisa naslovljenu Praznovjera i staroslavensko bajoslovlje (mithologija). ${ }^{10}$ Ako se zapitamo što magijske radnje ili praznovjerja rade u rukopisima koji opisuju tradicijski život devetnaeststoljetnih Hrvata, potrebno je naglasiti da je prikupljanje, zapisivanje i proučavanje vjerovanja i samih magijskih radnji tijekom druge polovice 19. stoljeća označeno kao jedno od polazišta za razumijevanje duhovnoga identiteta (ruralnoga dijela) naroda preko kojega će se bolje razumjeti cjelokupno ustrojstvo hrvatske kulture. ${ }^{11}$ Važnost tradicijskih

\footnotetext{
7 Žiža, Običaji, 1895-1899, HR-ETNOHAZU-SZ, kut. 72; Josip Ptašinski, Narodni život Hrvata i Slovenaca u Istri. 1899. Hrvatska - Odsjek za etnologiju Hrvatske akademije znanosti i umjetnosti - fond Stara zbirka, kut. 111.

8 Luka Šešo, Božo Jakovljević, “Žiža, Stjepan”, u: Istarska enciklopedija (Zagreb: Leksikografski zavod Miroslav Krleža, 2005), 924-925

9 Luka Šešo, "Ptašinski, Josip", u: Istarska enciklopedija (Zagreb: Leksikografski zavod Miroslav Krleža, 2005), 653-654.

10 Žiža, Običaji, 1895-1899, HR-ETNOHAZU-SZ, kut. 72, fasc. bII, eII, eV; Ptašinski, Narodni život. 1899. HR-ETNOHAZU-SZ, kut. 111. bilj VIII.

${ }^{11}$ Već je Ivan Kukuljević Sakcinski godine 1851. u prvome broju Arkiva za povjesnicu Jugoslavensku (dalje Arkiv) objavio jedan od prvih upitnika za prikupljanje etnografske građe. Njegova su pitanja, doduše, većinom bila usmjerena prema istraživanjima povijesti i arheologije kraja u kojemu bi potencijalni suradnik istraživao. Međutim, među 26 pitanja koja je Kukuljević objavio nalaze se i ona koja se odnose na život i kulturu puka, ali i na vjerovanja u nadnaravna bića. Tako pod rednim brojem 19. stoji pitanje: Šta kod vas pripověda puk o vilah, vešticah, coprnicah, viškah (...) o Sablasti, o Mori, i Morani, o kugi i o smrti? Sljedećih godina u Arkivu su se objavljivali odgovori prinosnika građe, odnosno opisi i nabrajanja navedenih bića (pretežno iz hrvatskih zemalja) kojih je s vremenom bilo sve više. Stoga je Kukuljević svakim novim brojem Arkiva širio broj pitanja u kojima su se ubrzo našla i pitanja o vukodlaku, maliku,
} 
vjerovanja - kao jednoga od elemenata (budućega hrvatskog) identiteta - zagovarao je i Antun Radić, koji će u svojoj Osnovi predvidjeti da suradnici na terenu zapisuju vjerovanja, a među njima i "Gatańe," "Bajańe" i "Vračke (čarolije)."12 Upravo stoga Radićevi suradnici na terenu svoj su rad jednim dijelom trebali usmjeriti i prema zapisivanju toga korpusa duhovne kulture. Iako nisu svi Radićevi suradnici uspjeli prikupiti gradivo o tradicijskim vjerovanjima, ${ }^{13}$ treba naglasiti da su neki uspjeli u tome. Većina rukopisnoga gradiva, u kojemu se obrađuju i tradicijska vjerovanja, dolazi iz Dalmacije, zatim Slavonije i sjeverozapadne $\mathrm{Hr}$ vatske. ${ }^{14}$ Međutim, većina tih rukopisa počet će pristizati u Odbor tek početkom 20. stoljeća, a u svega nekoliko rukopisa nalazimo samo kratke opise magijskih radnji. Jedina dva rukopisa s konca 19. stoljeća koja se odnose na Istru upravo su rukopis Stjepana Žiže, koji na više mjesta detaljno navodi magijske radnje te rukopis Josipa Ptašinskoga koji, iako u manjoj mjeri nego što to čini Žiža, nezanemariv prostor posvećuje opisima i tumačenjima magijskih radnji koje suvremenome čitatelju možda zvuče i uznemirujuće. No, budući da sve povijesne procese trebamo promatrati (i) u njihovome vlastitom, sinkronijskom kontekstu, namjera mi je promotriti povijesne, društvene, ekonomske i kulturne datosti koje su možebitno utjecale ili poticale stanovnike Istre da se koriste magijskim radnjama u 19. stoljeću.

\section{Magijske radnje - naredbe za postizanje konkretnih rezultata}

Što su zapravo prakticirali istarski seljaci u 19. stoljeću kada su mrtvačku kost skrivali pod platno na oltaru za vrijeme mise kako bi ju u neznanju blagoslovio svećenik i prenio na nju moći pomoću kojih će djevojka, koju takva kost takne,

patuljcima kao i o mjestima gdje žive vile i vještice odnosno "gdje se po narodnom pripovijedanju nalaze zli dusi i mitološka bitja." Vidi: Ivan Kukuljević, "Bajoslovlje i crkva", Arkiv za povjestnicu jugoslavensku 1 (1851): 241-242; Ivan Kukuljević, "Pitanja Družtva za jugoslavensku povjestnicu i starine na sve prijatelje domaćih starinah i jugoslavenske povjestnice", Arhiv za povjestnicu jugoslavensku 7 (1863): 350. Za daljnje čitanje o uporabi magijskih i mitskih elemenata pri formiranju nacionalnoga identiteta vidi: Zoran Čiča, Vilenica i vilenjak. Sudbina jednog pretkršćanskog kulta u doba progona vještica (Zagreb: Institut za etnologiju i folkloristiku, 2002), 15-18; Luka Šešo, Živjeti s nadnaravnim bićima. Vukodlaci, vile i vještice hrvatskih tradicijskih vjerovanja (Zagreb: Jesenski i Turk, 2016), 91-96;

12 Radić, "Osnova", 69.

${ }^{13}$ Antun Radić predvidio je da potencijalni suradnici skupljaju gradivo i zapisuju odgovore na sva njegova pitanja iz Osnove, ali je bio svjestan da je taj posao za mnoge prezahtjevan te je suradnicima savjetovao da se usredotoče na one dijelove tradicijskoga života njihove sredine koje im je lakše obraditi te koji su samim suradnicima zanimljiviji za istraživanje. Pored toga, Radićevu suradnju s prinosnicima građe narušavao je nedostatak financijskih sredstava zbog kojih su mnogi odustali prije nego što su kompletirali cjelokupan rad na rukopisu. Vidi: Radić, "Osnova”, 74; Primorac, "Arhivska građa”, 21-22,

${ }^{14}$ Više o broju rukopisa i lokalitetima iz kojih su pristizali u Odbor vidi: Ivana Polonijo, Luka Šešo, "Skupljači etnografske i folklorističke građe iz Dalmacije u rukopisnim kolekcijama ZbNŽO-a i Matice hrvatske pohranjenim u Etnološkom zavodu HAZU u Zagrebu”, Etnološka tribina 25 (2002), br. 32: 137-165; Batina et al., "Dokumentacijski pregled arhivskog gradiva Odsjeka za etnologiju Hrvatske akademije znanosti i umjetnosti”, Zbornik za narodni život i običaje 55 (2010): 45-149. 
samovoljno pristati na spolni odnos s počiniteljem? Je li to magija, religija, praznovjerje ili nešto treće? Premda se istarski seljak tim pitanjima vjerojatno nije previše opterećivao, povjesničari, etnolozi i antropolozi uložili su znatne napore kako bi definirali ove kategorije. Ukratko, ono što Žiža i Ptašinski zapisuju kao "čarovije" zapravo su magijske radnje. Međutim, ni danas nemamo jasno postavljene definicije tih vrijednosnih sustava i među znanstvenicima još uvijek postoje prijepori oko jasnih granica i preklapanja magije i religije. ${ }^{15}$ Ipak, tijekom devetnaestoga i dvadesetoga stoljeća neka tumačenja magije etablirala su se među brojnim znanstvenim pogledima i s vremenom su postala općeprihvaćena. Prvenstveno je riječ o tome da se magija promatra u svojoj različitosti prema religiji, odnosno u vrsti moći koja se priziva. Tako će magijom biti smatrane one radnje kojima se osoba obraća nadnaravnim silama za dobivanje konkretnih stvari. ${ }^{16}$ Religija, s druge strane, podrazumijeva radnje kojima se od nadnaravnih sila očekuje zadovoljenje čovjekovih apstraktnih želja. Naime, traženje spolnoga odnosa s djevojkom nešto je konkretno i stoga su radnje za postizanje toga cilja magijske. $S$ druge strane, vršenje radnji kojima bi se muškarac i žena spojili i bili prihvaćeni kod Boga i među ljudima (vjenčanje) religijski je čin jer pretpostavlja zadovoljenje apstraktnih želja. Druga važna različitost magije i religije leži u načinu na koji se osoba obraća nadnaravnim silama. Prema tome tumačenju osnovna značajka magije jest da određenim postupcima prisiljava nadnaravna bića na djelovanje, dok religijski čin pretpostavlja ponizno traženje i molitvu koju će nadnaravna bića (bogovi ili Bog) uslišiti ako smatraju da je to za čovjekovo dobro. U religiji bogove ili Boga trebamo štovati i biti ponizni kako bismo pridobili njihovu/ Njegovu naklonost, dok u magiji nadnaravne sile tretiramo mehanički, okrećući njihovu sveprožimajuću moć u svoju korist, slično kao što vodu možemo skrenuti na svoj mlin. ${ }^{17}$

Prema navedenim gledištima na određenje i razliku između magije i religije, ono što Žiža i Ptašinski nazivaju "čarovijama” odgovara značajkama magije. Stanovnici Istre mehaničkim radnjama - poput kuhanja crne mačke u ponoć ili krađe hostija - željeli su "narediti" nadnaravnim sferama postizanje konkretnih stvari,

\footnotetext{
${ }^{15}$ O definiciji magije i njezinome razgraničenju od religije i praznovjerja vidi: Edward Bever, "Magic and Religion", u: Encyclopedia of Witchcraft. The Western Tradition, ur. Richard M. Golden (Santa Barbara, California: ABC-CLIO, 2006), 695-696; Richard Kiechefer, Magic in the Middle Ages (New York: Cambridge University Press, 2000), 8-17; Daniel L. Pals, Eight theories of religion (New York, Oxford: Oxford University Press, 2006), 39-40; Šešo, Živjeti s nadnaravnim, 15-17.

${ }^{16}$ Srpski etnolog i folklorist Ljubinko Radenković na magiju gleda kao na niz simboličnih sustava i podsustava kojima čovjek želi ovladati vremenom i prostorom u kojemu živi. Stoga je za njega magija "simbolički instrument čiji je cilj da izazove promenu u željenom pravcu ili da sačuva postojeće stanje od neželjenih promena." Ljubinko Radenković, Simbolika sveta u narodnoj magiji Južnih Slovena (Niš: Biblioteka Slovenski svet, 1996), 6-7, 353. Dodatno o postizanju konkretnih stvari putem magijskih radnji vidi: Bronislaw Malinowski, Magic, Science and Religion and Other Essays (Garden City, New York: Doubleday Anchor Books, 1954), 86-87.

${ }^{17}$ Kieckhefer, Magic, 15.
} 
odnosno, kao što ćemo vidjeti, osigurati si zdravlje, besmrtnost, bogatstvo, zadovoljiti svoju požudu i seksualnost te se učinkovito osvetiti mrskim osobama.

Vrijedi pritom istaknuti da se ni Josip Ptašinski ni Stjepan Žiža ne slažu s takvim postupcima te obojica ističu kako su Hrvati primili kršćanstvo još prije tisuću godina i u svojim rukopisima opisuju mnoge kršćanske obrede. ${ }^{18} \mathrm{Na}$ više mjesta pokazuju kako su istarski stanovnici pobožni i dobri kršćani, odnosno katolici, ističući kako nema zabilježenih primjera "nikakove nove vjere." ${ }^{19}$ Dodatno se osvrćući na "čarovije," Ptašinski ističe da su to prežitci poganskih slavenskih vjerovanja koja su svima prirođena "budi si pobožnjak, seljak ili učenjak." ${ }^{20}$ No, među seljacima je praznovjerje ipak najraširenije i uzaludno je pokušati iskorijeniti ga, stoga Ptašinski zaključuje: "Tako ludost i bedastoća nije još izčesnula." ${ }^{21}$ Stjepan Žiža ipak je nešto "zabrinutiji” od Ptašinskoga kada govori o svojim zapisima "čarovija." Svjestan je da su to prežitci starijih poganih vjerovanja, međutim, prema kršćanskoj dihotomiji, u njima vidi štovanje vraga i suradnju sa zlim silama. Žižu dodatno brine i svrha takvih postupaka te objedinjujući svoja razmišljanja zaključuje: "Rabe se u opće čarovije u nepoštene svrhe, zato oni još ridki, koji ih zanju, nete povidati, pošto da je velika grihota, jer pop kod izpovjedi ih neće odrisiti, zato svaki dan propadaju. Nego govore, da ako će se što postignuti čarovijom, da se nesmije u Boga verovati, nego tvrdo u nje." 22

\section{Sukob s mrskim osobama}

Tragom Žižina zaključka i pozornijim čitanjem samih tekstova otkrivamo da su magijske radnje, kojima su istarski seljaci pribjegavali, zaista usmjerene na zagorčavanje života drugih, na krađu, osvetu ili samo vlastitu ugodu i probitak pri čemu se praktikanti nisu ustručavali u pomoć zvati tamne, nadnaravne sile. Iako je to značilo kršenje najsvetijih vrijednosti kršćanske vjere ili osudu na vječni pakleni oganj, ${ }^{23}$ neki su ipak odlučili magijskim radnjama rješavati životne "probleme" i zadovoljavati svoje želje.

Najveći broj magijskih radnji koje nalazimo u rukopisima Žiže i Ptašinskoga možemo svrstati pod zajednički nazivnik - sukob s mrskim osobama. Supružnici koji se nisu međusobno trpjeli, zavađeni susjedi ili djevojke i mladići povrijeđeni u ljubavi svrstavaju se u skupinu onih koji su se najčešće odlučivali za ovaj tip nadnaravnoga zlodjela. Osveta ili sukob najčešće je podrazumijevao vršenje

\footnotetext{
${ }_{18}$ Žiža, Običaji, 1899. HR-ETNOHAZU-SZ, kut. 72, fasc. eV, 30-36; Ptašinski, Narodni život, 1899. HRETNOHAZU-SZ, kut. 111, fasc. IV.

19 Žiža, Običaji, 1899. HR-ETNOHAZU-SZ, kut. 72, fasc. eV, 31.

${ }^{20}$ Ptašinski, Narodni život, 1899. HR-ETNOHAZU-SZ, kut. 111, fasc. VIII, 1, 31.

${ }^{21}$ Isto, 31.

22 Žiža, Običaji, 1899. HR-ETNOHAZU-SZ, kut. 72, fasc. eV, 36.

${ }^{23}$ Vidjeti Prilog, redni broj 20.
} 
magijskih radnji kojima bi se oponentima nastojao pomutiti razum. Kako bi to postigli, ljudi su o ponoći kuhali crnoga mačka čiji bi mozak potom stavljali u jelo onoga kojega su željeli učiniti ludim. ${ }^{24}$ Drugi način osvete podrazumijevao je opasne magijske radnje kojima su sklonije bile žene željne osvete nakon svađe sa suparnicom. Povrijeđena strana uzela bi posvećenu svijeću, užgala ju i okrenula gorjeti naopačke govoreći: "Kako od ove svijeće kaplje vosak, tako neka od tebe kapa meso." 25 Žena na koju je bio usmjeren taj čin navodno bi ubrzo teško oboljela. S nje bi se otkidalo meso i istekla sva krv te bi na kraju preminula. Međutim, ova čarolija bila je opasna i za samu praktikanticu. Naime, ako je u svađi, koja je prethodila cijelome procesu, kriva bila osoba koja je vršila magijsku radnju, tada bi ona bila zahvaćena činima te bi umrla u teškim mukama. Netrpeljivost, omraza i osvetoljubivost očituju se i u magijskoj radnji pod nazivom "kljuka," koju opisuju i Josip Ptašinski i Stjepan Žiža. Prema zapisima razvidno je da ovoj magijskoj radnji pribjegavaju ljubomorni mladići, odnosno oni koji nisu uspjeli oženiti odabranu djevojku, stoga dolaze na njezino vjenčanje kako bi kljukom uništiti ljubavni život budućega bračnog para. Da bi se izvela kljuka, koja može potrajati svega par dana, godinu ili vječno, mladić neuzvraćene ljubavi mora stajati u blizini crkve za vrijeme obreda vjenčanja i u ruci držati novčić koji presiječe na dvije polovice, a koje potom baci preko crkvenoga krova govoreći: "Kada se budu združile ove dvie polovice, tada neka se združe i oni." ${ }^{\prime 6}$ Drugi je način da ljubomoran mladić stoji u kutu crkve i u trenutku kada svećenik vjenčava mladence, vikne: "Lažeš." Time zazove samoga vraga, napravi čvor na konopu i dok ga ne razveže, mladenci ne mogu spolno općiti. ${ }^{27}$ Dakako, od kljuke se može obraniti i to na više načina. Jedan od njih nalaže da mladoženja tijekom vjenčanja klekne mladenki na suknju ne dopuštajući da zle čini naude njezinoj intimi. Druga je mogućnost da mladenci oko vrata nose zapise s čarobnim formulama koje odbijaju djelovanje zlih sila, a moguće je i obratiti se osobama s posebnim moćima koje se nazivaju "obrecljivci" i koje imaju moć skidati uroke i čarolije jednako kao što ih mogu i stvarati. ${ }^{28}$

Iz navedenoga primjera možemo zaključiti da je kljuka magijska radnja za koju su znali mnogi - i oni koji su ju stvarali i oni koji su se od nje štitili. Naime, magijske radnje kojima se željelo spriječiti konzumiranje braka, to jest spolno općenje, bile su raširene diljem Europe još od srednjega vijeka, a njima su pribjegavali ljubomorni mladići i u drugim dijelovima Hrvatske tijekom 19. i 20. stoljeća. ${ }^{29}$ Iako bismo prema opisima koje donose Žiža i Ptašinski mogli zaključiti da iza svega

\footnotetext{
${ }^{24}$ Vidjeti Prilog, redni broj 1.

25 Vidjeti Prilog, redni broj 2.

${ }^{26}$ Vidjeti Prilog, redni broj 4.

27 Vidjeti Prilog, redni broj 5.

28 Vidjeti Prilog, redni broj 5. i 8.

${ }^{29}$ Više o magijskoj radnji pod nazivom kljuka vidi: Evelina Rudan. “Kljuka or about Impotence, Legends and Antithesis”. Narodna umjetnost: hrvatski časopis za etnologiju i folkloristiku 48 (2011), br. 1: 129-145.
} 
stoje ljubomorni mladići, primjeri iz regije i prošlosti pokazuju da se zapravo radi o pomanjkanju seksualnoga iskustva i nervozi zbog koje mladenci nisu uspjeli konzumirati brak prve bračne noći te su za to optuživali zle čini, to jest osobe koje bi im htjele nauditi iz ljubomore. ${ }^{30} \mathrm{U}$ prilog tome da je ljubomora bila jedan od čimbenika zbog kojih su se ljudi u Istri silovito osvećivali suparnicima govori i rečenica koju navodi Stjepan Žiža: "Imade digod adulteria, ali toga naš čovjek ne more trpiti, ako nije od civilizacije pokvaren, jer se često čuje od muži, da bi volili biti u Kopru (Kaznioni) nego biti jarac." ${ }^{31}$ Premda nam navedena rečenica ne otkriva da su muževi vršili magijske radnje kako bi se osvetili ljubavniku svoje žene, ona ipak ukazuje na odlučnost, ali i nepromišljenost pojedinaca koji nisu birali sredstva pri činu osvećivanja. Ne želim ići tako daleko da povezujem magijske radnje s osvetom iz ljubomore, ali ljubomora i već spomenuta omraza bili su jedan od glavnih pokretača za vršenje magijskih radnji. ${ }^{32} \mathrm{O}$ tome nam opet svjedoče opisi koje donose Žiža i Ptašinski, a u kojima se spominje da su neki svojim suparnicima uz pomoć magijskih radnji prevrtali kola na ravnoj cesti, ${ }^{33}$ dok bi drugi čak plaćali gregorijanske mise i zapletali grane od loze vjerujući da će se tako zaplesti i crijeva njihovih neprijatelja koji bi potom preminuli. ${ }^{34}$

\section{Zadovoljavanje požude}

Osim ljubomore i omraze primjeri koje navode Žiža i Ptašinski pokazuju da su ljude na vršenje magijskih radnji dodatno tjerali požuda i strast. Jedan od takvih primjera opisuje magijsku radnju pri kojoj muškarac, da bi pridobio određenu ženu, mora otići duboko u šumu do mjesta gdje se ni s jedne strane ne može čuti pijetlovo kukurikanje. Na tome mjestu oko sebe mora nacrtati krug, a živoga crnog mačka staviti kuhati u nerabljeni kotao. Dok mačak cvili kuhajući se, oko kruga stoje vragovi, viču i reže tako da je moguće i umrijeti od velikoga straha. Kada mačak ugine, vragovi odlaze. Kuhano mačje meso kao i još jednu žabu čovjek mora odnijeti na mravinjak. Kosti koje ostanu na mravinjaku trebaju se

\footnotetext{
${ }_{30}$ Rudan, "Kljuka", 134; Šešo, Živjeti s nadnaravnim, 214.

31 Žiža, Običaji. 1899. HR-ETNOHAZU-SZ, kut. 72, fasc. eII, 30.

${ }^{32} \mathrm{U}$ dva svoja dosadašnja rada već sam problematizirao spregu ljubomore, omraze i magijskih radnji. Naime, tijekom novovjekovnoga perioda progona vještica u Europi, kao i u hrvatskim tradicijskim vjerovanjima 19. i 20. stoljeća, pojedinci i skupine upravo su zbog ljubomore i omraze optuživali žene iz svoje zajednice da su vještice tvrdeći da su one svojim zlim, nadnaravnim moćima prouzročile zlo optužitelju. U tome procesu, doduše, nisu optužitelji bili ti koji su vršili magijske radnje, ali su samo vršenje magijskih radnji pripisivali mrskim osobama i onima na koje su bili ljubomorni kako bi ih demonizirali, stigmatizirali i sankcionirali, to jest osvetili im se. Vidi: Luka Šešo, "Which woman is a witch? The stereotipic notionas about witches in Croatian traditional beliefs", Studia ethnologica Croatica 24 (2012): 195-207; Šešo, Živjeti s nadnaravnim, 206-213.

${ }^{33}$ Vidjeti Prilog, redni broj 3. i 8.

${ }^{34}$ Vidjeti Prilog, redni broj 6. i 7.
} 
smrviti i staviti u jelo željene osobe nakon čega bi se ona dobrovoljno podala. ${ }^{35}$ Sličan učinak postiže se na način naveden u uvodnome primjeru ovoga rada. Naime, o ponoći se s groblja ukradena mrtvačka kost mora odnijeti u crkvu gdje se izgovaraju neke tajne formule za vrijeme Sv. mise. Nakon toga se s mrtvačkom kosti može dotaknuti djevojka koja se želi imati, a ona bi tada svojevoljno pošla za onim koji ju je taknuo i ne bi ga napustila dokle god je živa. Takne li se djevojka po goloj koži, navodno bi počinitelju svaki dan dolazila potpuno gola. ${ }^{36}$

Osim crnih mačaka, žaba i mrtvačkih kosti magijske radnje koje osiguravaju naklonost suprotnoga spola podrazumijevale su i uporabu vlastite krvi, majčinoga mlijeka ili kuhanoga cvijeća, koje se stavljalo u hranu osobe koja se želi pridobiti. ${ }^{37}$ Nerijetko su se takve radnje nadopunjavale s kršćanskim obredima. Jedan od takvih obreda bilo je i vjenčanje tijekom kojega su mladoženjini roditelji nastojali saznati je li njihova buduća snaha djevica i stoga dostojna njihova sina. Kako bi to postigli, ubili bi zmiju, odsjekli joj glavu, zakopali je u vrtu i na nju posadili tri zrna boba. Kada bob izraste, samelji bi njegove plodove te bi ih umijesili u dva okrugla kolačića koja bi stavili na oči kada mladenka pristupa oltaru. Ako mladenka nije djevica, oko glave bi se, umjesto svadbenoga vijenca, mogle vidjeti zmije kako plaze. ${ }^{38}$

\section{Krađa i nevidljivost}

Suvremenome čitatelju možda će se najuznemirujućim činiti magijske radnje koje su vršili lopovi kako bi nesmetano krali po selu. Kako bi bili uspješniji u svojemu "zanatu," lopovi su najčešće pribjegavali magijskim radnjama koje su ih činile nevidljivima. To je podrazumijevalo ubijanje i kuhanje crnoga mačka čije bi kosti lopovi potom stavljali pod jezik kako bi navodno postali nevidljivi. Mnogo brutalniji oblik magijske radnje, a koji navode i Žiža i Ptašinski, bio je ubijanje trudnice iz čije bi utrobe lopovi izvadili dijete. Odsječene djetetove udove koristili bi kao baklje jer su vjerovali da se pred tako dobivenim svjetlom otvaraju sva vrata i pokazuju skriveni novci te se pritom nitko ne može probuditi i spriječiti ih u krađi. ${ }^{39}$ No, iako ih ljudi možda nisu mogli vidjeti, seoski psi mogli su ih nanjušiti. Stoga bi lopovi o ponoći na groblju krali mrtvačke kosti. Kosti bi zapalili i pretvorili u pepeo koji bi pomiješali s kruhom i dali prvome seoskom psu. Ubrzo nakon toga svi bi psi u selu prestali lajati, a lopovi bi neometano krali. ${ }^{40}$ Dakako, postojale su i magijske radnje protiv lopova, koje su nalagale da oštećeni na groblju uzme

\footnotetext{
${ }^{35}$ Vidjeti Prilog, redni broj 9.

36 Vidjeti uvodni primjer i Prilog, redni broj 11.

37 Vidjeti Prilog, redni broj 13.

${ }^{38}$ Vidjeti Prilog, redni broj 10. i 12.

39 Vidjeti Prilog, redni broj 16 i 17.

${ }^{40}$ Vidjeti Prilog, redni broj 18.
} 
mrtvačeve kosti, ovoga puta prste djeteta koje za života nije zgriješilo. Njih bi vršitelj radnje oko ponoći kuhao u nerabljenome loncu. Kada bi usred noći voda zakipjela, počela bi se tresti kuća, a iz dimnjaka bi se čuo strahoviti vražji glas koji pita gospodara što želi. On bi nabrojao stvari koje su mu otuđene, a vrag bi poslao oganj da peče savjest onoga lopova koji bi od muke ubrzo vratio sve pokradene stvari. $^{41}$

Na kraju spomenimo kako Ptašinski navodi još jednu magijsku radnu kojoj su pribjegavali lopovi i drugi nasilni ljudi. Riječ je o "macakanu" ili čarobnome kladivu koje su lopovi punili mljevenim mrtvačkim kostima te su ga pri obredu krštenja potajice krstili zajedno $s$ djetetom. Takvo kladivo, na koje su (prema vjerovanju) prenesena nadnaravne moći, koristilo se za udaranje žrtve ili neprijatelja. Čovjek udaren macakanom ne bi vidio tko ga je udario te bi se razbolio i ubrzo preminuo. ${ }^{42}$

\section{Zdravlje i neranjivost}

U posljednju skupinu magijskih radnji o kojima nas izvještavaju Žiža i Ptašinski možemo ubrojiti one koje služe za postizanje zdravlja i neranjivosti. Lopovi, vojnici, ali i obični ljudi vršili su magijske radnje koje bi ih očuvale od protivničkoga metka. Kako bi to postigli, praktikanti bi krali svete hostije koje bi potajice vadili iz usta nakon pričešćenja. Potom bi si rasporili komad kože na tijelu te bi u ranu zašili sv. hostiju vjerujući da ih nakon toga puščani metak ne može ubiti. ${ }^{43}$ Postizanje zdravlja i liječenje teških bolesti također je podrazumijevalo vršenje određenih magijskih radnji, ${ }^{44}$ međutim, na ovome mjestu treba naglasiti da ove prakse Žiža i Ptašinski ne uvrštavaju u cjelinu rukopisa u kojima pišu o "čarovijama." Tek će Žiža pod "čarovijama” opisati liječenje nekoliko bolesti među kojima i epilepsiju (bolest sv. Valentina), zmijski ugriz i bolesti pod nazivom "mrtva kost." Na kraju opisa, koji ponovno govore o odlascima na groblje, mrtvačkim kostima koje moraju gristi djeca mlađa od sedam godina te uslugama "obrecljivaca," Žiža izjavljuje: "Za druge bolesti, za koje se služi s naravnimi srestvi, ni treba da kažem." ${ }^{45}$ Iz posljednje rečenice razvidno je da Žiža pribjegava autocenzuri te da je već pomalo zasićen, a možda i zabrinut zbog magijskih radnji koje je zapisao i koje će u svojemu rukopisu poslati Antunu Radiću u Zagreb. Josip Ptašinski, s druge strane, nema "problema" s bilježenjem. Liječenju teških bolesti i ozdravljenju posvetit će cijelu devetu bilježnicu naslovljenu Prostonarodna Pathologija

\footnotetext{
${ }_{41}$ Vidjeti Prilog, redni broj 15.

42 Vidjeti Prilog, redni broj 19.

43 Vidjeti Prilog, redni broj 18. i 20.

${ }^{44}$ Više o hrvatskim tradicijskim vjerovanjima o uspješnosti liječenja magijskim radnjama vidi: Aida Brenko, Željko Dugac, Mirjana Randić, Narodna medicina (Zagreb: Etnografski muzej u Zagrebu), 121-127.

45 Vidjeti Prilog, redni broj 21., 22. i 23.
} 
i therapija ili bolest $i$ liječenje bolesti. ${ }^{46}$ Već na prvim stranicama navest će da su prakse liječenja spoj kršćanskih vjerovanja, travarstva, praznovjerja te "svakojakih zaklinjačkih formula i tajnih stvari," a da je za "one bolesti potrebo zvati boga i vraga u pomoć." ${ }^{47}$

\section{Zašto su istarski stanovnici vršili magijske radnje?}

Iščitavanjem rukopisa Žiže i Ptašinskoga moguće je primijetiti da se oba autora na svojevrstan način ograđuju od magijskih radnji koje bilježe. U Žižinom rukopisu, kao što je već navedeno, razabire se zabrinutost pa čak i odbojnost prema pojedincima koji su kršili kršćanski svjetonazor vršeći magijske radnje. Stoga opisivanje nekih primjera Žiža naglo prekida rečenicama poput: "Ali to su stvari jako kosmate, pa neću da ih kažem, jer i vraga zovu na pomoć"."48 Time Žiža odaje da su se u njegovome rukopisu mogle naći još mnoge magijske radnje koje bi u svojemu opisu bile kudikamo "kosmatije," ali budući da se Žiža od njih želi ograditi, ipak ih ne nalazimo u izvoru. S druge strane Ptašinski, koji je bio svećenik, na magijske radnje prvenstveno gleda kao na "bedastoće," pogansko praznovjerje i prežitke iz razdoblja kada Slaveni još nisu primili kršćanstvo. Međutim, osim što autore "muči" kolaboracija s vragom i slavensko poganstvo, treba istaknuti da oba autora primjećuju da same magijske radnje obiluju okrutnošću i svetogrđem. Onaj tko ih vrši jest nepošten jer krši moralne, vjerske i zakonske odredbe. Pored toga, ciljevi tih istih radnji također su nepošteni jer su podrazumijevali osvećivanje, krađu, zadovoljavanje požude i postizanje neranjivosti. Stoga će Žiža zabrinuto istaknuti kako je vršenje magijskih radnji praktikantima onemogućavalo odrješenje grijeha zbog čega bi neki umirali u teškim mukama. ${ }^{49}$

Jesu li istarski stanovnici u 19. stoljeću bili pogani, primitivni, moralno devijantni i okrutni u svome, gotovo bestijalnom, ponašanju koje se manifestira u opisanim magijskim radnjama? Iako spomenuti primjer, u kojemu lopovi vade dijete iz trudničke utrobe, ide u prilog navedenome ponašanju, smatram kako bi bilo ishitreno "osuditi" istarske seljake bez detaljnijega čitanja rukopisa Žiže i Ptašinskoga. Naime, ako u dosadašnjemu tijeku rada to nije bilo dovoljno razvidno, treba naglasiti da je iz rukopisa Žiže i Ptašinskoga moguće iščitati da je riječ o djelima pojedinaca i manjih skupina iz ruralnih krajeva Istre. Stoga ne možemo generalizirati i tvrditi da su magijske radnje bile dijelom svakodnevice svih ili barem većega broja stanovnika Istre. Drugo, i za ovaj rad presudno, jest ukazati na to da Žiža i Ptašinski zapravo nisu pisali o svojemu vremenu. Iako su oba rukopisa nastala u posljednjemu desetljeću 19. stoljeća, u njima se zapravo nalaze obrisi

\footnotetext{
${ }^{46}$ Ptašinski, Narodni život, 1899. HR-ETNOHAZU-SZ, kut. 111, fasc. IX.

47 Isto, str 2.

48 Vidjeti Prilog, redni broj 11.

49 Vidjeti Prilog, redni broj 20.
} 
prijašnjega stanja. Naime, prateći naputke Odbora, to jest Osnovu Antuna Radića, suradnici na terenu zapisivali su narodni život i običaje seljaka na temelju informacija dobivenih od tih istih seljaka. ${ }^{50}$ Dakako, velik broj dobivenih informacija u rukopisima zaista predstavlja odraz vremena u kojemu su informacije prikupljene, međutim, veliki dijelovi rukopisa zapravo su zapisi sjećanja kazivača/seljaka koji prenose ono što su čuli od starijih ljudi kada su oni sami bili mladi. Tako na više mjesta, u dijelu rukopisa posvećenome magijskim radnjama, Žiža zapisuje rečenice poput: "Kod nas jedan put kako starci pripovidaju, ljudi bi doživili veliku starost, posto ih je manje bilo. Živili su polag pripovidanja u nekakovom primitivnom stanju" ili "Narod pripovida da jedan put je bia poša djavâ u nekoga čovika (...)." ${ }^{51}$ Navedene rečenice otkrivaju kako je do podataka Žiža dolazio slušajući pripovijedanja "naroda" i staraca koji su pak pripovijedali o prošlim događajima i nekakvome prošlom "primitivnom stanju." O tome da je Žiža svoj rukopis sastavio na temelju informacija dobivenih od starijih osoba posvjedočit će i nekoliko neobilježenih listova papira koji se nalaze među bilježnicama Žižina rukopisa. ${ }^{52}$ Na njima je Žiža zapisao imena pedeset "povidača" i "povidačica" te je uz svako ime naveo nekoliko napomena koje nam otkrivaju da je većina Žižinih sugovornika bila starije životne dobi. Tako otkrivamo da je neki Stjepan Katonar iz Tara imao šezdeset godina, Marija Pokrajac, rođena Kveštić iz Muntrilja, 88 godina, a određena Marija Pokrajac iz Šijane, u trenutku izrade popisa sugovornika, već je bila pokojna, što ukazuje na mogućnost da je i ona bila jadna od onih "staraca." Drugim riječima, Žiža, u dijelu rukopisa posvećenomu čarolijama, većinom donosi podatke koji nisu odraz posljednjega desetljeća nego, u najmanju ruku, prve polovice devetnaestoga stoljeća. ${ }^{33}$ Štoviše, u nekoliko sljedećih rečenica Žiža će nam otkriti točno razdoblje u kojemu su pojedinci vršili magijske radnje, a koje će on zapisati prema pripovijedanju starijih.

Pišući o nedjelima lopova i pljačkanju uz pomoć magije, Žiža ističe kako danas: "Takovih tamo nije, ni varlica ni krijončara. (...) Sada malo se čuje za krađu, i to kakovu ovcu ili janca za pojisti i malo grozđa za prodati." ${ }^{54}$ Dakle, u trenutku kada Žiža zapisuje magijske radnje, lopova, varalica i krijumčara navodno nema (barem ne u većoj mjeri). No, njih i njihovih zlodjela svakako je nekoć bilo i o tome u Žižinome vremenu pripovijedaju stariji. To vrijeme Žiža otkriva u sljedećemu odlomku rukopisa:

${ }^{50}$ Radić, "Osnova”, 74.

${ }^{51}$ Žiža, Običaji, 1899. HR-ETNOHAZU-SZ, kut. 72, fasc. eV, 19.

52 Žiža, Običaji, 1899. HR-ETNOHAZU-SZ, kut. 72.

${ }^{53}$ U rukopisu Josipa Ptašinskoga ne nalazimo rečenice ili popis suradnika koji bi nam eksplicitno ukazivao na to da je Ptašinski do podataka dolazio od starijih osoba kao što je to u Žižinome slučaju. Međutim, ne nalazimo ni argumente koji bi to opovrgavali. Štoviše, zbirka korespondencije iz Odbora pokazuje da je Ptašinski, jednako kao i Žiža, surađivao s Radićem i pratio njegove naputke, stoga možemo zaključiti da su Ptašinski i Žiža imali vrlo sličnu metodologiju rada. Vidi: Primorac, "Arhivska građa", 19.

${ }^{54}$ Isto, fasc. eII, 26. 
"Jedan put dokle nije bilo žandarmarije bilo je puno tati i krelo se je volove, ovce i više puta po kućah. Nema više kumpanijah hajdukah, kako je bilo u po zapadnoj Istriji iza promijene vlade Austrijske i Franceske. Tada povidaju da je bilo više kunpanijah dižerturah, koji su stanovali u šumskih pećinah, i ovi da bi čekali ljude na putu ki pokreli, isto tako pošli bi i kuće i dvore pokresti (...) Pod Franceskom vladom mnogi bijahu ulovjeni i na dube ubiseni. I pod sadašnjom vladom bijaše ih još ostalo, ter se do njih još domišljaju nekoji stari ljudi. Povida se od onih dižerturih da svaki od njih da je ima pistolu i sablju, i da oni su znali drugomu uzeti oganj, to jest način da olovo ih ne more ubiti." 55

Navedeni odlomak, koji nalazimo u dijelu rukopisa posvećenome magijskim radnjama, ukazuje da su te iste radnje vršene u periodu kada su postojali zločinci i svojevrsna društvena anarhija i hajdučija. Taj period, kako nam prispodobljuje Žiža, poklapa se s promjenom vlasti u Istri, odnosno s razdobljem kada u Istri prestaje francuska uprava i počinje austrijska. Ne trebamo biti preveliki poznavatelji hrvatske povijesti kako bismo zaključili da je riječ o drugome desetljeću devetnaestoga stoljeća. ${ }^{56}$ Da ne bi bilo zabune, Žiža pojašnjava da danas: "Povidaju stari ljudi da ona vrimena da bi došli na Misu svi muži obaružani, i da bi pred vrati od crikve prija Mise učinili gomilu od oružja, i na svršetku Mise uzeli svaki svoje." ${ }^{57}$ Kako bi dodatno približio mentalitet vremena u kojemu su ljudi vršili magijske radnje, Žiža u post scriptumu promatranoga dijela rukopisa zapisuje crticu koju naslovljava Sedam sakramenata Zbandajskih:

"P. S. Jedan put kako povidaju starci u Istri se je mnogo krelo. Pripovida se da u Ćićariji jedan nisu hotili učiniti čovjeka za župana, ako nije 10 godina učinio u kazijoni, Žbandaje obćina Porečka ima svojih sedan sakramenti starih:

Sedan Sakramenti Zbanjdajskih:

Prvo. Ukredi.

Drugo. Doma donesi.

Treto. Uderi.

Četvrto. Skuhaj.

Peto. Poji.

Sesto. Ninomu ne povi.

Sedmo. Ni za strah, ni za sram, ni za nikavu rič na svitu. - Amen.

\footnotetext{
${ }^{55}$ Isto, 26-27.

${ }^{56}$ Francuska je na čelu s Napoleonom zauzela bivši mletački dio Istre 1805. godine, a nakon rata s Austrijom 1809. godine svoju vlast proširuje i na austrijski dio Istre. Iste godine Istra će postati dijelom Ilirskih pokrajina, koje će nakon Napoleonova poraza u Bitci kod Austerlitza 1813. godine potpasti pod vlast Austrijskoga Carstva. Više o francuskoj upravi Istre vidi: Nevio Šertić, Napoleon u Istri. Istra za francuske uprave 1805-1813 (Pula: Istarska književna kolonija "Grozd", 1989).

57 Žiža, Običaji, 1899. HR-ETNOHAZU-SZ, kut. 72, fasc. eII, 28.
} 
Sada više nema tamo tatbine." 58

Posljednji Žižin zapis otkriva mnogo elemenata važnih za našu priču. Kao prvo, Žiža ponavlja da su "starci" ti koji pripovijedaju kako je bilo u prošlosti, što nas dodatno ohrabruje u tvrdnji da je riječ o vremenu koje je prethodilo samome nastanku rukopisa. Druga zanimljivost jest ukazivanje na prošlo stanje $\mathrm{u}$ istarskome društvu (Ćićarija) u kojemu su se cijenile i postavljale na vodeće položaje one osobe koje su barem deset godina provele u zatvoru. No, očito je kako taj mentalitet nije lokalan (Ćićarija), nego je prisutan i u drugim dijelovima Istre (Žbandaj, Poreč). Takvo društvo, sklonu kriminalu i nedjelima, iznjedrilo je i vlastite zapovijedi koje autor naziva "sakramentima" kako bi, vrlo vjerojatno, dodatno istaknuo nemoralnost, bezbožnost i bezvlađe onoga vremena. Štoviše, svaki od sedam "sakramenata" ukazuje da je društvo koje ih je slijedilo bilo sebično, beskrupulozno te sklono kriminalu i krađi. Naposljetku, autor zaključuje kako takvoga ozračja u njegovo vrijeme više nema.

Dakako, navedeni zapis, u kojemu Žiža povezuje određene seoske zajednice s kriminalom i nemoralom, treba motriti cum grano salis. Naime, čitatelj se lako može prikloniti stereotipima i generalizacijama koje su zbog mogućih lokalnih netrpeljivosti bile prisutne među stanovnicima Istre Žižina vremena, a suvremenome čitatelju ostaju skrivene. Isto tako, kao što je već rečeno, u rukopisima je razvidno Žižino distanciranje od "nepoštenih" prošlih vremena u kojima su mjesto našle i magijske radnje, stoga je sklon naglašavanju alteritera u perspektivi vremena ističući da u njegovo vrijeme nema hajdučije, lopovluka i magijskih radnji kao što je to bilo nekad. Ipak, nije uputno ni zanemariti Žižine opise nego ih valja promotriti u društvenome kontekstu onoga vremena.

Koje je to vrijeme, već smo naveli, ali osim što smo naveli da se u tome vremenu dogodila promjena vlasti, treba ukazati i na posljedice koje je ta promjena prouzročila te promotriti ekonomske i društvene prilike u kojima se promjena odvijala.

Pojašnjenje o tome u kakvim je prilikama bila Istra tijekom drugoga desetljeća 19. stoljeća potražit ćemo kod Miroslava Bertoše. U knjizi Izazovi povijesnog zanata. Lokalna povijest i sveopći modeli Bertoša jedno poglavlje naslovljuje Treći jahač apokalipse. Istra u doba gladi i tifusa $(1815-1818)^{59}$ i tako već nagovješćuje u kojemu se smjeru kreće pojašnjenje. No, istaknut ću još jednu Bertošinu rečenicu: "Istra se kretala ususret kratkoj ali vrlo dramatičnoj kataklizmi." ${ }^{60}$ Ukratko, Miroslav Bertoša u svojemu radu, koji je većim dijelom temeljio na proučavanju arhivskoga gradiva, ukazuje da se Istra u prvim desetljećima 19. stoljeća nalazila

\footnotetext{
${ }^{58}$ Isto, fasc. eV, 37.

${ }^{59}$ Miroslav Bertoša, Izazovi povijesnog zanata. Lokalna povijest i sveopći modeli (Zagreb: Izdanja Antibarbarus, 2002), 59-114.

${ }^{60}$ Isto, 64 .
} 
u izrazito nepovoljnome ekonomskom i društvenom stanju. Sukobi Napoleona, Venecije i Habsburgovaca desetkovali su, među ostalima, i stanovništvo Istre. Nakon Napoleonskih ratova vojnici su diljem Europe, a tako i Istrom, širili pjegavi tifus koji se prenosio ušima. Bolest je ubrzo prerasla u epidemiju koja je 1817. godine dosegnula vrhunac te je dodatno utjecala na smanjenje broja stanovnika. Posljedice ratovanja prouzročile su i visoke cijene žitarica i hrane te se u Istri pojavljuje glad čiji se vrhunac 1817. godine poklapa s epidemijom tifusa. Pritom, prva desetljeća 19. stoljeća obilježena su propalim urodima zbog niza hladnih ljeta, koja Bertoša povezuje s "malim ledenim dobom" koje se u Europi pojavljivalo u intervalima između 1580. i 1850. godine. Istarsko stanovništvo nije moglo odgovoriti izazovima novonastaloga stanja zbog nerazvijenoga gospodarstva i zdravstvenoga sustava te je učinak gladi, bolesti i siromaštva bio katastrofalan. Broj stanovnika u Istri smanjio se za trećinu, a prosječna duljina životne dobi iznosila je svega 23-24 godine. Bertoša ističe kako se zbog neizvjesne sutrašnjice i apokaliptičnoga stanja ljudi nisu odlučivali na sklapanje brakova te znatno opada i broj porođaja. Štoviše, Bertoša nam nudi opise izmučenih seljaka koji lutaju šumama i cestama u potrazi za hranom. Opisuje slučajeve u kojima gladni jedu žirove i hranu namijenjenu psima. Djeca ostaju bez roditelja i postaju prosjaci. Leševi onih koji se nisu mogli prehraniti leže uz ceste, a mnogi upadaju u stanja patološkoga straha zbog kojega napuštaju dom i umiru izmučeni glađu. Takvo apokaliptično stanje, koje je u Istri svoj klimaks imalo 1817. godine, protegnut će se i na sljedeće desetljeće, a posljedice će se, u nekim dijelovima Istre, osjećati još dugi niz godina. ${ }^{61}$

Bertošina istraživanja istarskoga društva prvih desetljeća 19. stoljeća svakako predstavljaju novi trenutak pri priučavanju magijskih radnji toga vremena. Uzmemo li u obzir socioekonomske prilike kroz koje su istarski stanovnici morali prolaziti u prvim desetljećima 19. stoljeća, postavljam pitanje: možemo li sada jasnije gledati na magijske radnje? Možemo li neizvjesnu svakodnevicu prouzročenu bolešću, glađu i ratovima povezivati s čovjekovom željom da se iz takvoga stanja "izbavi” i "zadovolji” svim dostupnim sredstvima, pa čak i ako ona podrazumijevaju suradnju s vragom, ubijanje trudnica, krađu hostija i mrtvačkih kosti?

\section{Umjesto zaključka}

Spomenimo kako Bertoša navodi da njegovo istraživanje ukazuje na mogućnost da se u promatranome razdoblju smanjio stupanj religioznosti u Istri s obzirom da su ljudi napuštali svoju djecu i obitelj te su umirali bez sakramenta bolesničkoga pomazanja. Međutim, Bertoša ipak tvrdi da se u ljudima nije izbrisao tvrdo ukorijenjeni religiozni mentalitet jer su u velikome broju prisustvovali procesi-

${ }^{61}$ Isto, 80, 86. 
jama koje je organizirala Crkva. ${ }^{62}$ Ipak, uzmemo li u obzir svrhu zbog koje su se procesije organizirale, a to je uspješnost ljetine, to jest manipulacija vremenom, mogli bismo zaključiti da se same procesije približavaju svrsi koju po definiciji imaju magijske radnje, a to je postizanju nečega konkretnog poput proizvodnje hrane neophodne za život. Drugim riječima, istarski stanovnici u prvim desetljećima 19. stoljeća željeli su preživjeti i podmiriti svoje osnovne životne potrebe u vremenima kada su slike lutajućih, gladnih i pljački sklonih naoružanih družina bile dio svakodnevice. Anarhoidno stanje koje spominje i Žiža čini se da je iznjedrilo mnogo pojedinaca i skupina spremnih na otimačinu i sukob. Niti agresori niti žrtve unutar tih procesa nisu se ustručavali utjecati nadnaravnim silama za pomoć. Neki su to činili religijskim obredima moleći za urod i čekajući da Bog usliši njihove molitve. Drugi su te ciljeve željeli postići "preko reda" pritom zanemarujući svoju religioznost i posežući za magijskim radnjama koje bi im omogućile da u kratkome vremenu krađom i lopovlukom osiguraju egzistenciju. U takvome apokaliptičnom i neizvjesnom vremenu neophodno je bilo ostati živ i očuvati zdravlje, stoga se javljaju (ili oživljuju) magijske radnje koje osiguravaju neranjivost i zdravlje. Isto tako, budući da u promatranome razdoblju opada broj brakova i porođaja te uopće spremnost za seksualnim odnosom, ${ }^{63}$ možemo pretpostaviti da je mnogima zadovoljenje tjelesne požude bilo kudikamo teže nego što bi to bilo u razdoblju prosperiteta. Nisu li upravo zbog toga pojedinci pribjegavali magijskim radnjama koje bi im u kratkome vremenu trebale pribaviti "predmet" njihove požude? Smatram da magijske radnje, zapisane u rukopisima Žiže i Ptašinskoga, ukazuju da bi odgovor na ovo pitanje mogao biti potvrdan. Osvrnimo se naposljetku i na magijske radnje kojima su se ljudi osvećivali mrskim osobama te onima na koje su bili ljubomorni. Već sam naveo da u razdobljima krize jačaju sukobi unutar zajednice koja počinje tražiti "demone" i žrtvenu janjad za svoje nedaće. Naime, magijske radnje u tim procesima počinju biti alat osvete/sukoba s neprijateljima. Ratovi, bolesti, glad i teško prihvatljiva stanja na seoskoj mikrorazini pojačavaju vjerovanja u postojanje vještica, vukodlaka i magijske manifestacije tamnih sila. ${ }^{64}$ Toga je donekle svjestan i Miroslav Bertoša, koji pred kraj svojega istraživanja navodi kako su propale ljetine, hladne godine i apokaliptično ozračje u Europi na početku 19. stoljeća uvelike potaknuli mladu englesku spisateljicu Mary Wollstonecraft (Shelly) na objavljivanje romana o Frankensteinu (1818.). Sljedeće godine John William Polidori, koji je zajedno s

\footnotetext{
${ }^{62}$ Isto, 85 .

${ }^{63}$ Isto, 87.

${ }^{64}$ Više o dimenzije magijskoga i nadnaravnoga pri sukobu na seoskoj razini vidi: Elliot Rose, A Razor for a Goat. A Discussion of Certain Problems in the History of Witchcraft and Diabolism (Toronto, Buffalo, London: University of Toronto Press, 1989); Briggs, Robin. Witches \& Neighbors. The Social and Cultural Context of European Witchcraft (Harmondsworth, Middlesex, England: Viking. 1996); Brian P. Levack, "Scapegoats", u: Encyclopedia of Witchcraft. The Western Tradition, ur. Richard M. Golden (Santa Barbara, California: ABC-CLIO, 2006), 1010; Šešo, Živjeti s nadnaravnim, 203-230.
} 
Mary Shally i Lordom Byronom bio dijelom družine koja je u ljetnim mjesecima 1816. godine boravila u hladnim i tmurnim švicarskim Alpama, objavit će kratku priču Vampir (1819.) i time utrti put drugim, mnogo slavnijim književnim ostvarenjima o neumrlom krvopiji. Kasnije ćemo saznati da su mladi književnici svoju inspiraciju pri kreiranju demonskih bića pronašli upravo u apokaliptičnoj i hladnoj 1816. - godini prozvanoj "godinom bez ljeta." Naime, 1816. - godinu dana prije dramatičnoga klimaksa gladi i epidemije u Istri - erupcija indonezijskoga vulkana promijenila je klimu i Europu okovala u hladnoću i tamu. ${ }^{65}$ Tako su se vulkanski oblaci udružili s glađu, epidemijom i ratovanjem stvarajući poligon na kojemu se odigravao cijeli spektar nadnaravnoga, demonskoga i magijskoga. U želji da svoje izmučeno tijelo "oslobode" od gladi i neimaštine te da mu ujedno osiguraju život, smatram kako su pojedinci i skupine u Istri (i ne samo ondje) posezali za magijskim radnjama. Strah od neizvjesne sutrašnjice, u kojoj pojedinac magijskim radnjama bira život ovozemaljski pred životom vječnim, uzrokovat će pomak u mentalitetu istarskoga seljaka. Taj pomak mnoge će okrenuti traganju za zadovoljenjem materijalnih dimenzija života pomoću magijskih radnji pri čemu će kompromitirati vlastitu religioznost. Toga su, vjerujem, bili svjesni i Žiža i Ptašinski kada su se zabrinuto osvrtali na magijska (ne)djela istarskih stanovnika. No, obojica su također bila svjesna da je ovaj dio kulture i povijesti istarskoga "naroda" nužno zapisati kako bi svjedočio o mnogostrukosti i složenosti svakodnevice i mentaliteta "naroda." Upravo za takvim informacijama tragao je i Antun Radić kojemu Ptašinski u posljednjim rečenicama svojega rukopisa kao da šalje poruku oslikavajući stanje (mentaliteta) istarskih stanovnika:

"Mnogo je još bolesti i tajnih lieka i zaklinjanja proti njima u puku (...) Mnogo formula potiče još od staropoganskih doba; mnoge jesu veoma praznovjerne i dapače proti vjeri (...) Ovdje ima još mnogo djela škola, crkva i vlada da priškoče zapuštenom narodu na pomoć." 66

\footnotetext{
${ }^{65}$ Više o utjecaju erupcije vulkana u Indoneziji na europsku svakodnevicu vidi: William Klingaman, Nicholas Klingaman, The Year Without Summer: 1816 and the Volcano that Darkened the World and Changed History (New York: St. Martin's Press, 2013).

${ }^{66}$ Ptašinski, Narodni život. 1899. HR-ETNOHAZU-SZ, kut. 111, fasc. IX, 14-15.
} 


\section{PRILOZI:}

\section{Odabrane magijske radnje iz rukopisa Narodni život Hrvata i Slovenaca u Istri Josipa Ptašinskoga i Običaji hrvatskog naroda Istre Stjepana Žiže}

\section{Sukob s mrskim osobama ${ }^{67}$}

\section{1 .}

Kako se čini da čovjek(a) iz uma izadje (impazzire) ${ }^{68}$

Da se postigne da čovjek ide iz pameti, uzeti se mora posve črnonoga mačka, i živoga se stavi u pokriveni kotao kuhati dokle izkuha. Onda uzmu se moždjani i stavi se ih u jelo onoga, koji se hoće da iz uma izadje, i stvar da je gotova, stari ljudi povidaju. Tako da su činili u staro vreme muž kada nije moga trpiti svoje ženu ili ona njega. Tako mladić kad ga nebi hotila djevojka uzeti, ili ona njemu. ${ }^{69}$

2.

Kako se čine umrieti žene jedna drugu, koje živu u mržnji

Za to učiniti, da ženska učini umrieti svoju neprijateljicu, uzme voštenu svieću od Svete Marije, naopo ju užge i govori: Kako od ove svieće kaplje vosak, tako da bi od tebe meso kapalo amen. Malo zatim da ona ženska se uboli, i sve meso na njoj da izgine, i krv iz nje izteče ter da zastalno umre uzrokom one operacije.

Nego govore da umre ona, koja tako učini proti svojoj neprijateljici ako je ona kriva njihoj svadji. ${ }^{70}$

3.

Kako se čini da voz na ravnom izvnuti

Uzme se jednu pučinko i se ju zabode u svieću Svete Marije, svieću se užge da gori do pučinke, kad je do nje izgorila, se ju izvadi i nosi sobom. Kad se hoće da se izvrne kočija obrne se glavu ona onu stran, koju se hoće da se izvrne.

Neki rabe i vieticu od zakona, što nadje se u grobu od zapane žene; ali za takove stvari postignuti, se mora nešto govoriti, što ja neznam. ${ }^{11}$

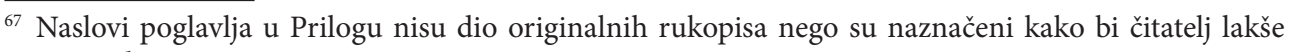
pratio tijek rasprave.

${ }^{68}$ Nazivi samih magijskih radnji, ako ih ima, navedeni su prema izvorniku.

${ }^{69}$ Žiža, Običaji, 1895. HR-ETNOHAZU-SZ, kut. 72, fasc. bII, 11.

${ }^{70}$ Isto, 12.

${ }^{71}$ Isto, 14.
} 
4.

\section{Kljuka}

Kljuka, zovu zaprieka, koju da učine medju mladoženjom i mladom nevjestom u crkvi, kad bih pop zakoni, da nemogu skupa puteno obćiti, što da se učini iz srčbe, ako djevojka neće da uzme mladića, koji je ju prije prosio. Kljuku se načini za malo dana, za više godina, i za uvjek, što govore da je veliki grih, koje izpovjednik neće da odrieši. Više je načina da se kljuku načini, ali pravo nete da kažu oni, koji znadu. Govore, da kada ih svećenik u sveti zakon združuje, onda onaj, koji hoće da načini kljuku, stoji bližu crkve držeć u ruci razsječen novac na pol, i pô ga baci preko crkve i reče: Kada se budi združile ove dvie polovice, tada neka se združe i oni, tako da se načini za uvjek, budući da pol novca se sakrije ili u jamu ili u vodu baci. Na drugi način se načini, isto u crkvi kod S. mise kad ih svećenik u ženidbu ždruzuje. Onaj, koji hoće da to učini, mora biti prisutan u kakvom kutu crkve, i pop kada otoča Misu, onaj mu mora svakoj rieči odgovorati "lažeš," i kad pop mladince u zakon združuje učini neki ovežalj na koncu, i dokle se onaj ovežalj nerazveže oni da nemogu skupa obćiti. Mladenci kada su u crikvi pri zakonu mladoženja klekne mladoj visti na kotole da im kljuka neudi. ${ }^{72}$

5.

Kljuka kod zakona

Kljuka je njeka čarovija, koju naravi načinjač mladoženjom kod zakona, da se nemogu skupa sastati u sv. matrimoniju i da nemogu skupa djece imati. Pred kljukom imaju njekoji praznovjerni ljudi ovakov strah, da gledaju se zakoniti rano u jutro i kod zatvorenih vrata, kada nije drugih ljudi u crkvi. Kljuku da učini neprijatelj mladoženjom sa sazivanjem vraga i zaveže špag, vezalj pa baci u vodu ili ga zatuče na remež na glavlju, a kljuka je učinjena. Da razbiju kljuku mnogo se trude i poskuse svakojaka sredstva n.pr. da si muž obuče košulju od žene i prsten od zakona postavi sebi i udre š njim u zid govoreć: "Koliko sam naudio tomu zidu, toliko naudila svaka sljeparija našem zakonu, pomogla nas prečista djevica Marija!” Drugi opet napišu si na papiru rieči: "U ime Isusa i Marije, neka se razkinu sve sliparije; uprišta se obratilo i nam niš ne naudilo i u niš se izvrglo. Amen!” Ovu molitvicu nose oko vrata i vjeruju, da razkinu kljuku. Načinjači imaju da rzkinu kljuku, iz koje mole vrhu ovakvog muža i žene, te dobivaju zato obilne darove. ${ }^{73}$

6.

Misa suha i gregorijanska

Misu takovu daju misiti, ako hoće neprijatelju nauditi, da usahne ili da mu se scrieva uviju i td. ali da je onaj, koji da misiti takovu misu, ima veliki grieh. Ako će

72 Isto, 16.

${ }^{73}$ Ptašinski, Narodni život, 1899. HR-ETNOHAZU-SZ, kut. 111, fasc. VIII, 16. 
osloboditi dušu svojih pokojnih od čistilišća, kažu da je treba postići "suhi post" to je nejesti ništa od velikog četvrtka, kada "se zaveže (zatvori) gloria do velike subote, kada se razveže Alleluja" i dati za dušu tog pokojnika misiti sedam misa i to jednu za drugom bez prekidanja, kojim kažu mise gregorijanske i da je duša takovog oslobodjena iz čistilišća. ${ }^{74}$

7.

Trtoples

Ako hoće, da čovjeku oviju se crijeva, uviju njeko drvo na žuli od loze, a onakov čovjek mora umrijeti. To učini iz osvjete svom neprijatelju! $!^{75}$

8.

Obreci

Jesu ljudi, koji bi čovjeku zlim okom naudili sobrekom, i to mnogoputa, s pomoć vraga mogu napraviti, da se voz na ravnom putu zvrne. Ovakovim ljudima govore obrecljivci. Obrecljivac može postati čovjek, koji se po tri dana neumije ili koji se obrne kod podizanja sv tjela u crkvi. ${ }^{76}$

\section{Zadovoljavanje požude}

9.

Kako se čini žensku po volji doći kamo se hoće

Uzme se zato posve črnoga mačka, pa se mora ići daleko u šumu gdje se nečuje od nijedne strane petehov glas. Koji hoće da to učini, okolo sebe učini veliki kolombar (circolo) stavi živoga mačka u nerabljeni kotao, pod njim loži oganj, dokle on skiči, vragovi stoje okolo kolombara, viču na svaki mogući način, tako da je moguće umrieti od velikoga straha. Kada mačak pogine, tada vrazi odlaze. Mačka pečeno se ponese na mravište da ga mravi izjedu, se uzme malu žabicu (Laubfrosch) i nju se stavi na mravište dokle ju mravi izjedu. One koste se uzme, stare i stavi u kakvo jelo i dade onoj ženski, koja hoće da za njim dodje po volji. ${ }^{77}$

10.

Kako se učini da se pozna jeli mlada neviesta diva (vergine)

Govore, da se ubije zmija, da se joj odsječe glava, zakopa u vrta i na nju posadi tri zrna boba. Kada bob uzrije, se samelje, a iz muke se umjesi kolač, kojega se stavi

\footnotetext{
${ }^{74}$ Isto, 22.

${ }^{75}$ Isto, 35 .

${ }^{76}$ Isto, 23.

77 Žiža, Običaji. 1895. HR-ETNOHAZU-SZ, kut. 72, fasc. bII, 13.
} 
na oči kada grede mlada neviesta zakonu. Ako nije dieva okolo glave se joj vide zmije na mjesto vienca. ${ }^{78}$

\section{1.}

Kosti se moraju pojti kresti po noći na viliju Božju, i nositi ih sobom na Misu, i svaki put kada pop na oltaru reče amen, a onaj, koji ima kost reče lažeš. Pa takvom koštjom ako se takne divojku ili ženu tada sama da ide za čovikom. Takove kosti rabe za mnoge čarovije, kako i Prisvetu Ostiju. Ali to su stvari jako kosmate, pa neću da ih kažem, jer i vraga zovu na pomoć. ${ }^{79}$

12.

Njekoje su protivne nesamo vjeri, ali su i zlorabe osobito njekoje čarovije, među kojimi su n.pr. začarati djevoku od mladića s pomoću mrtvačkih kosti; ako se hoće poznati, ako je nevjesta djevojka, odsječu glavu zmiji i zakopaju u zemlju tri zrna boba iz ovoga pak ploda sameljenog učine kolač s mukom pa kad se zakone, gledajuć kroz njega, govore, da se vidi zmije na glavi, ako nije djevojka. Ako hoće djevojku omamiti, nakaplje njekoliko kapljica mladić u vino, a djevojka se zaljubi u njega do smrti, ili uzmu mrtvačku kost, pa ju postave na oltar i ju onda nose oko vrata. ${ }^{80}$

\section{3.}

\section{Ljubav učarati}

U Istri govore, da je moguće mladiću ili djevojci načarati, da se jedan u drugog saljubi. U toj svrhi kuhaju jedan drugomu ljubavno cvieće ili nakaplju njekoliko kapljica svoje krvi u čašu vina i to daju popiti jedan drugome, ne da bi znao ili isto tako par kapljica meterinskog mlieka. Onaj koji to popije, da je za drugim "munjen" od ljubavi. Mužki čine za sobom poći djevojku, da joj daruju rubac, kojega je od prije "od njekih beštija (slieparija) činio okrvaviti." Ovaka djevojka da je "munjena za tim mužkim i mora poć za njim." ${ }^{11}$

\section{Krađa i nevidljivost}

14.

Kako se učini da pas ne laje ni čovjeka neujede

Na badnji u pol noći se gre na groblje se uzme mrtvačku neku kost, se ju izgori, i

\footnotetext{
${ }^{78}$ Isto, 15.

${ }^{79}$ Isto, 1899. HR-ETNOHAZU-SZ, kut. 72, fasc. eV, 36.

${ }^{80}$ Ptašinski, Narodni život, 1899, HR-ETNOHAZU-SZ, kut. 111, fasc. VIII, 21.

${ }^{81}$ Isto.
} 
onaj lug se zamjesi s mukom se učini hlieb, dade se pojesti prvom psu, kojeg se slučajno prvoga dobije. To da bi činili u staro vrieme, kad su hodili dvore pokresti. ${ }^{82}$

15.

Kako se učini da mu sam tat donese ukradenu stvar

Rabe mrtvačke kosti kada komu što ukradu (orudje ili zlato, kolo i što slična, da mu sam tat donese ukradenu stvar. Zato kažu da uzmu u grobu ruku (prste) od andjela, one kosti se moradu kuhati u nerabljenom loncu, za kojega se mora dati koliko zahtjeva lončar kad ga prodaje, to se mora kuhati od 11 - 12 ure po noći, kada voda zakuha (zavrije) da se kuća počme tresti, a iz dimljaka da se čuje neki strahoviti glas da pita gospodara što mu manjka (a to da je vrag) gospodar da odgovori, mi manjka ona stvar, ja ću je imati, dobro dobit ćeš ju čim prije. A tat odmah da mu ponese ukradenu stvar, jer oganj da ga počee. ${ }^{83}$

16.

Povidaju još neki stari ljudi, da jedan tati da bi ubili ženu noseću i izvadili dite iz nje. Odrizali ruke i noge, i ove bi užgali, kad bi pošli po kućah kresti. Kad bi se služili takovima svićami nitko u kući da ne bi mogao zbuditi. Drugi bi nosili mrtvačke kosti u sebi da ih puška ne ubije. Mrtvačke kosti rabe za razne čarovije, kako očarati divojku. ${ }^{84}$

17.

Tati i kradenje s pomoću čarovije

O polnoći ustane tat i užge ruku "mrtvog djeteta." Ona ruka da mora biti od djeteta još iz utrobe majčine izvadjeno, da se mater ubiti i dijete iz nje izvaditi, a s ovom rukom da se može mnogo stvari učiniti, jer svieti ona sama u noći, kažu, gdje su novci uloženi, otvore sama vrata, ključanice, otajno zaspi sve u kući itd. /.../ Druga čarovija tata je to, da ukradu vošćenu svieću, u crkvi, te onomu, komu će skratitit život zapale i drže naopako, i kako kaplja svieća, tako da se skraća njegov život. ${ }^{85}$

18.

Tati opet rabe mrtvačku kos, da ju izgore te ju zamješaju onaj prah s mukom i učine kruh. Taj kruh dadu jesti psu, pa ne laje više i mogu bez zaprieke krasti. Više puta poskuse načiniti njeku ugodbu s vragom, da se obogate, ili lovci pojedu

\footnotetext{
${ }_{82}$ Žiža, Običaji. 1895. HR-ETNOHAZU-SZ, kut. 72, fasc. bII, 15.

${ }^{83}$ Isto, 19.

${ }^{84}$ Isto. 1899. HR-ETNOHAZU-SZ, kut. 72, fasc. eV, 35.

${ }_{85}$ Ptašinski, Narodni život, 1899. HR-ETNOHAZU-SZ, kut. 111, fasc. VIII, 35.
} 
na Veliki petak srce od zeca, da mogu ubiti svaku živinu s puškom ili da ih ne zadjene nijedna kruglja. ${ }^{86}$

19.

\section{Macakan (čarobno kladivo, bat)}

Macakan i čarobno kladivo je kršteno kao kršćan, a da je veliki grieh učiniti to. Kada idu krstiti djete postave macakan, u kojem su kosti mrtvih ljudi, pod glavu djeteta, a da je kršćena kod krsta na mjesto djeteta. Po Pučkom mnienju ima vrag kod krsta svoje prste, jer se s ovim macakanom može ubiti čovjeka i živinu, ne da bi znao odkud ga je ovo nevidljivo vražje oružje udarilo, a takav čovjek mora do tri dana umrieti ili izgubiti pamet, a nezna od koga je bio udaren. Na mjesto macakana učine opet drugi "pasju palicu," koja je šuplja i u njoj su stučene kosti svakojakih živina i mrtvih ljudi i nema tako veliku oblast kao macakan, ali svejedno nezna udreni od koga je bio udren. ${ }^{87}$

\section{Zdravlje i neranjivost}

20.

Da čovjeka olovo iz puške nemore ubiti, ako ga nepogodi zgora dihala (zgora usti) zato se učini tako. Kada se ide na S. Pričištjenje, na mjesto progutati Svete Ostiju, da se izvadi iz grla, i poslije da si čovjek razpori malo kože na tjelu i unutra stavi, tako olovo iz puške da ga neubije. To da bi činili prvašnja vriemena tati, i vojnici prije nego bi išli u rat.

Ovo preznovierje gubi se svaki dan više, te ovo barbaričko znanje da umiju samo neki zli ljudi, koji više godina u svojem životu po tamnicah učinili, ali pa je drugih, koji mnoge stvari znadu razkinuti. Ovakve neke stvari nete podnipošto da druge nauče, jer svećenik da ih nemore odriešiti, a drugačije da pretežko umru. ${ }^{88}$

21.

Kada zmija ujede čovjeka ili životinju, naši ljudi gredu do nekojih osobah, da načine da onaj čovjek ili životinja nepogine. Imade više nacina, kojimi se oni ljudi služe u takovoj priliki kad su pozvani. Njekoji mogu načiniti bez da dodju čoviku ili životinji, samo da im se kaže ime od ujidenoga. Drugi opet dodju da vidu čovjeka ili životinju, pak se odaleću, dokle vide drobnoga kamenja. Tada digne jedan kamičić strima prsti, i stavi ga u žep ili koji sud, na isti način uzme

\footnotetext{
${ }^{86}$ Isto, 42-43.

${ }^{87}$ Isto, 21.

88 Žiža, 1895, HR-ETNOHAZU-SZ, kut. 72, fasc. bII, 20.
} 
drugoga i tretoga. Grede k ujidenomu i mu stoji iz boka te počme recitirati svoju tajnu formolu:

Vrag je vraga ujia,

I vrag vraga neka lići.

Svaki kamik kada baci priko ujidenoga to izgovori. ${ }^{89}$

22.

\section{Mrtva kost}

Kada, koji ima mrtvu kost na ruci, ili di drugdi, gredu na groblje, uzmu kost od mrtvaca, pa s njom učini križ na nati (mrtvoj kosti) Ali prije mora jeno dite iz pod 7 lit (angjel) u jutro natašte zagristi onu natu za 7 ili 9 jutri, i svaki put učini križ na njoj s kostju od mrtvaca. Onaj, koji ima natu, mora svako jutro smoliti 1 očenaš za onu dušu čija je kost. Oni, koji su imali, kazali su mi da su tako učinili, i mrtva kost da im izčeznula. ${ }^{90}$

23.

Bolest S. Valentina

Onaj koji ima takovu bolest, mora pojti u 11 uri po noći na groblje i se pritakati tri pute na onom grobu, koji je zadnji zakopan dokle ure tuku za drugi put, i zvati po imenu mrtvaca za 3 pute po imenu, i mu reči: Ja ti izručujem moju bolest. I tako govore da se ozdrave. Ali moraju sami pojti, za već od njih je strah.

Za druge bolesti, za koje se služi s naravnimi srestvi, ni treba da kažem. ${ }^{91}$

${ }^{89}$ Isto, 21-22.

${ }^{90}$ Isto, 1899, HR-ETNOHAZU-SZ, kut. 72, fasc. eII, 32.

${ }^{91}$ Isto, 33. 


\section{Izvori}

Ptašinski, Josip. Narodni život Hrvata i Slovenaca u Istri. 1890-1899. Odsjek za etnologiju Hrvatske akademije znanosti i umjetnosti - fond Stara zbirka, kut. 111. Žiža, Stjepan. Običaji hrvatskog naroda Istre. 1895-1899. Odsjek za etnologiju Hrvatske akademije znanosti i umjetnosti - fond Stara zbirka, kut. 72.

\section{Objavljeni izvori i literatura}

Batina, Klementina; Marković, Jelena; Polonijo, Ivana; Primorac, Jakša; Šešo, Luka. "Dokumentacijski pregled arhivskog gradiva Odsjeka za etnologiju Hrvatske akademije znanosti i umjetnosti”. Zbornik za narodni život i običaje 55 (2010): 45-623.

Bertoša, Miroslav. Izazovi povijesnog zanata. Lokalna povijest i sveopći modeli. Zagreb: Izdanja Antibarbarus, 2002.

Bever, Edward. "Magic and Religion". U: Encyclopedia of Witchcraft. The Western Tradition, uredio Richard M. Golden, 692-968. Santa Barbara, California: ABCCLIO, 2006.

Brenko, Aida; Dugac, Željko; Randić, Mirjana. Narodna medicina. Zagreb: Etnografski muzej Zagreb. 2001.

Briggs, Robin. Witches \& Neighbors. The Social and Cultural Context of European Witchcraft. Harmondsworth, Middlesex, England: Viking, 1996.

Čiča, Zoran. Vilenica i vilenjak. Sudbina jednog pretkršćanskog kulta u doba progona vještica. Zagreb: Institut za etnologiju i folkloristiku, 2002.

Kieckhefer, Richard. Magic in the Middle Ages. New York: Cambridge University Press, 2000.

Klingaman, William; Klingaman, Nicholas. The Year Without Summer: 1816 and the Volcano that Darkened the World and Changed History. New York: St. Martin's Press, 2013.

Kukuljević, Ivan. "Pitanja na sve prijatelje domaćih starinah i jugoslavenske pověstnice”. Arhiv za povjestnicu jugoslavensku 1 (1851): 241-243.

Kukuljević, Ivan. "Pitanja Družtva za jugoslavensku povjestnicu i starine na sve prijatelje domaćih starinah i jugoslavenske povjestnice". Arhiv za povjestnicu jugoslavensku 7 (1863): 348-351.

Levack, Brian P. "Scapegoats". U: Encyclopedia of Witchcraft. The Western Tradition, uredio Richard M. Golden, 1010 -1011. Santa Barbara, California: ABCCLIO, 2006.

Malinowski, Bronislaw. Magic, Science and Religion and Other Essays. Garden City, New York: Doubleday Anchor Books, 1954. 
Marković, Mirko. "Osvrt na stogodišnjici rad Odbora za narodni život i običaje". U: Spomen-spis povodom obilježavanja stogodišnjice postojanja i rada Odbora za narodni život i običaje Južnih Slavena u sastavu Jugoslavenske akademije 18881988, uredio Andre Mohorovičić, 5-35. Zagreb: Jugoslavenska akademija znanosti i umjetnosti, Odbor za narodni život i običaje, 1988.

Pals, Daniel L. Eight theories of religion. New York, Oxford: Oxford University Press, 2006.

Polonijo, Ivana; Šešo, Luka. "Skupljači etnografske i folklorističke građe iz Dalmacije u rukopisnim kolekcijama ZbNŽO-a i Matice hrvatske pohranjenim u Etnološkom zavodu HAZU u Zagrebu”. Etnološka tribina 25 (2002), br. 32: 137-165.

Primorac, Jakša. "Arhivska građa Odsjeka za etnologiju HAZU”. Zbornik za narodni život i običaje 55(2010): 9-38.

Radenković, Ljubinko. Simbolika sveta u narodnoj magiji Južnih Slovena. Niš: Biblioteka Slovenski svet, 1996.

Radić, Antun. "Osnova za sabiranje i proučavanje građe o narodnom životu". Zbornik za narodni život i običaje Južnih Slavena 2 (1897): 1-88.

Rose, Elliot. A Razor for a Goat. A Discussion of Certain Problems in the History of Witchcraft and Diabolism. Toronto, Buffalo, London: University of Toronto Press, 1989.

Rudan, Evelina. "Kljuka or about Impotence, Legends and Antithesis". Narodna umjetnost : hrvatski časopis za etnologiju i folkloristiku 48 (2011), br. 1: 129-145.

Šetić, Nevio. Napoleon u Istri. Istra za francuske uprave 1805-1813. Pula: Istarska književna kolonija "Grozd”, 1989.

Šešo, Luka; Jakovljević, Božo. “Žiža, Stjepan”. U: Istarska enciklopedija, uredio Robert Matijašić, 924-925. Zagreb: Leksikografski zavod Miroslav Krleža, 2005.

Šešo, Luka. "Ptašinski, Josip". U: Istarska enciklopedija, uredio Robert Matijašić, 653-654. Zagreb: Leksikografski zavod Miroslav Krleža, 2005.

Šešo, Luka. "Which woman is a witch? The stereotipic notionas about witches in Croatian traditional beliefs". Studia ethnologica Croatica 24 (2012): 195-207.

Šešo, Luka. Živjeti s nadnaravnim bićima. Vukodlaci, vile i vještice hrvatskih tradicijskih vjerovanja. Zagreb: Jesenski i Turk, 2016.

Žiža, Stjepan, “Čarolije. (Iz Istre)”. Zbornik za narodni život i običaje 19 (1914), br. 1: 190-191. 


\title{
For revenge, lust, and theft: Magical Practices of $19^{\text {th }}$-Century Istrians as a Reflection of the Unfavourable Socioeconomic Situation
}

\author{
Luka Šešo \\ Catholic University of Croatia \\ Ilica 242 \\ 10000 Zagreb \\ Croatia \\ E-mail: luka.seso@unicath.hr
}

\section{Summary}

This paper analyses the manuscripts of Stjepan Žiža's Customs of the Croatian People in Istria and Josip Ptašinski's Folklore of Croats and Slovenes in Istria. Both manuscripts were written in the late $19^{\text {th }}$ century, when the Yugoslav Academy of Sciences and Arts launched a call for collecting sources on the folklore of South Slavic peoples. Among the numerous manuscripts received by the Academy, these two are particularly important as their authors paid special attention to the description of "sorcery" performed by the Istrians in the early $19^{\text {th }}$ century. Following the current theoretical literature, this paper treats the acts of "sorcery" as magical practices, since they invoke supernatural forces in order to obtain earthly benefits. These magical practices have been grouped into those aimed at revenge or satisfaction of lust, facilitating theft, and ensuring health or invulnerability. All analysed magical practices include blasphemy, brutality, and collaboration with Satan. Starting from the comments of the manuscript authors, who expressed their worries over the godless acts performed, the paper shows that the period in question coincided with a difficult socioeconomic situation. In an almost apocalyptic climate following the Napoleonic wars, particularly in the period from 1810-1830, the Istrian peninsula was struck by a devastating typhus epidemic and famine owing to unfavourable climatic conditions. Its population was decimated, crimes multiplied, and living expectancy was only 27 years. In such atmosphere, individuals and groups, primarily from the rural areas, resorted to magic in order to ensure health and wealth, or to satisfy their lust, in order to overcome the calamities of their everyday life.

Keywords: magical practices, Istria, $19^{\text {th }}$ century, manuscripts, Stjepan Žiža, Josip Ptašinski, epidemic, famine, rural society 